\title{
Effect of Supply of Metabolizable Protein on Splanchnic Fluxes of Nutrients and Hormones in Lactating Dairy Cows
}

\author{
J. P. Blouin, ${ }^{\star, 1}$ J. F. Bernier, ${ }^{*}$ C. K. Reynolds, $\dagger$ \\ G. E. Lobley , P. Dubreuil§, and H. Lapierre\| \\ *Département des sciences animales, Université Laval, Ste-Foy, Qc, Canada, G1K 7P4 \\ †Department of Agriculture, The University of Reading, Reading, UK, RG6 6AT \\ ¥Rowett Research Institute, Bucksburn, Aberdeen, UK, AB21 9SB \\ §Faculté de médecine vétérinaire, Université de Montréal, St-Hyacinthe, Qc, Canada, J2S 7C6 \\ ||Dairy and Swine Research and Development Centre, Agriculture and Agri-Food Canada, Lennoxville, Qc, Canada, J1M 1 Z3
}

\begin{abstract}
The effect of the supply of metabolizable protein on splanchnic fluxes of nutrients and hormones was measured in six catheterized late-lactation Holstein cows in a crossover design. Two isonitrogenous diets (16.3\% $\mathrm{CP})$, but differing in rumen protein degradability and estimated metabolizable protein (MP) supply (1654 g/ d, Lo-MP; 1930 g/d, Hi-MP) were fed, each over a 35-d experimental period. On d 34 or 35 , net fluxes of nutrients and hormones across the portal-drained viscera, the liver, and total splanchnic tissues were determined. Portal absorption of total, essential, nonessential, and branched-chain amino acids (AA) increased with the Hi-MP diet. Approximately $76 \%$ of the additional metabolizable protein supply was recovered as extra AA$\mathrm{N}$ absorption in the portal vein. Liver removal of AA was not different between diets, and this resulted in a greater net release across the splanchnic tissues for the Hi-MP diet. This extra AA supply provided substrates for the observed increased milk protein yield for the Hi-MP diet. Fractional efficiencies of conversion of absorbed individual essential AA into milk protein ranged from 0.42 to 0.68 . The corresponding efficiencies for utilization of postsplanchnic AA supply were 0.42 to 1.80. Provision of methionine, phenylalanine, and histidine beyond the liver were similar to outputs in milk protein but the other essential AA were supplied to peripheral tissues in excess of milk output, indicative of oxidative mechanisms in nonhepatic tissues. Net fluxes of glucose, $\mathrm{NH}_{3}-\mathrm{N}$, and urea were not affected by the diets. Neither arterial concentrations of insulin, somatotropin, or IGF-1, nor net transfers across the portal-drained viscera or liver of insulin, were affected by the diets. Although portal release of glucagon was
\end{abstract}

Received December 10, 2001.

Accepted April 12, 2002.

Corresponding author: H. Lapierre; e-mail: lapierreh@agr.gc.ca.

${ }^{1}$ Actual address: Shur-Gain, 5 Place du Commerce, suite 200, Brossard, QC, Canada, J4W 3E7. not different between the diets, a smaller proportion was removed by the liver on the Hi-MP diet. Metabolism of AA across the splanchnic tissue bed is a major determinant of the quantity and the profile of AA delivered to peripheral tissues.

(Key words: amino acids, splanchnic, metabolism, cow)

Abbreviation key: BCAA = branched-chain AA, EAA = essential AA, Hi-MP = high supply of metabolizable protein, Lo-MP = low supply of metabolizable protein, MP = metabolizable protein, NEAA = nonessential AA, pAH = para-aminohippurate, $\mathbf{P D V}=$ portal-drained viscera, $\mathbf{T A A}=$ total AA, TSP = total splanchnic tissues, VA $=$ venous-arterial .

\section{INTRODUCTION}

The total splanchnic tissues (TSP) exert a dual role in supply and utilization of nutrients and hormones. For example, while the portal-drained viscera (PDV) is the site of nutrient absorption, both for energy and protein-derived substrates, it is also a major consumer of VFA (Seal and Parker, 1994), glucose (Huntington, 1997), and amino-acid carbon (Lobley et al., 1996; Berthiaume et al., 2001). The PDV is also the site of release of both insulin and glucagon, two hormones that play opposing roles in protein anabolism and AA catabolism within the body. Both of these hormones are extracted by the liver, and the ratio of these extractions affects both hepatic AA oxidation (and hence ureagenesis) and the anabolic signals to peripheral tissues (Bergman and Pell, 1985). At the same time, the liver also removes substantial proportion of absorbed AA (Reynolds et al., 1988a) and, therefore, has a direct impact on AA made available to peripheral tissues (Lapierre et al., 2000a). This removal is a composite of a multi-function role, involving both obligate hepatic needs (e.g., AA carbon for gluconeogenesis, plasma protein synthesis), and removal of excess AA (with subsequent deamination to urea), coordinated with periph- 
eral tissue requirements, such as milk protein synthesis. Across the TSP, therefore, a complex interplay between nutrient supply and nutrient use with hormonal production and extraction is needed to integrate the metabolic responses related to animal productivity.

The question is then to understand, and subsequently utilize, this complex interplay to make greater and more efficient use of feedstuffs. A number of factors are recognized to improve animal production. Among these is the use of protein feedstuffs of lower rumen degradability, if related to increased duodenal protein flow (Santos et al., 1998). Most of the current attempts that relate such predicted, or observed, duodenal supply to milk output, rarely include data on the vital transformations and metabolic events that occur during absorptive and hepatic metabolism. For example, only one study describes such information for diet protein quality in relation to TSP metabolism of individual AA in cows at the beginning of lactation (Bach et al., 2000).

The current study starts to address this gap in our knowledge by comparing two diets differing in ruminal protein degradability and predicted metabolizable protein (MP) supply, with changes in net AA release into the portal vein and removal by the liver. These responses, plus those of energy metabolites (glucose and NEFA) and hormones (insulin, glucagon, somatotropin, IGF-1), were then related to postsplanchnic nutrient supply and milk protein output.

\section{MATERIALS AND METHODS}

\section{Animals and Treatments}

Six multiparous Holstein cows, averaging $597 \pm 39$ $\mathrm{kg}$ of BW and $210 \pm 7 \mathrm{DIM}$ at the start of the experiment, were housed in tie stalls in a heated barn (approximately $15^{\circ} \mathrm{C}$ ) lighted from 0600 to $2200 \mathrm{~h}$. Chronic indwelling catheters were surgically implanted as described by Huntington et al. (1989). Briefly, Teflon catheters sheathed in silicone tubing were implanted into a hepatic vein and the portal vein, while Tygon catheters were inserted into two mesenteric veins and into the caudal aorta, via a mesenteric artery. The right carotid artery was surgically raised to a subcutaneous position to provide access to arterial blood, should the aorta catheter fail (this occurred for one cow). The trial began at least 4 mo after the surgery, subsequent to a previous experiment (completed one month earlier).

Two diets, balanced for $\mathrm{N}(16.3 \% \mathrm{CP})$ and energy (1.62 Mcal $\mathrm{NE}_{\mathrm{I}} / \mathrm{kg}$ ), but differing in ruminal protein degradability (Tables 1 and 2), were tested within each cow according to a crossover design. One diet was estimated (NRC, 2001) to provide more MP (1930 g/d, HiMP), through increased RUP, compared with the other $(1654 \mathrm{~g} / \mathrm{d}$, Lo-MP). Metabolizable protein requirements
Table 1. Composition of two isoenergetic and isonitrogenous diets supplying high or low metabolizable protein (MP).

\begin{tabular}{lcc}
\hline & \multicolumn{2}{c}{ Treatments } \\
\cline { 2 - 3 } Ingredients & High MP & Low MP \\
\hline Corn silage & 338 & 330 \\
Grass hay & 229 & 225 \\
Corn & 240 & $\ldots$ \\
Soybean meal & 77 & $\ldots$ \\
Wheat distillers & 41 & $\ldots$ \\
Corn gluten meal & 5 & $\ldots$ \\
Canola meal & 46 & 40 \\
Rolled wheat & $\ldots$ & 371 \\
Urea & $\ldots$ & 11 \\
Mineral \& vitamin premix & 25 & 24 \\
Estimation from NRC (2001) & & \\
NE ${ }_{\mathrm{L}}$, Mcal/kg DM & 1.62 & 1.62 \\
Crude protein, \% DM & 16.3 & 16.3 \\
RDP, g/d & 1818 & 2206 \\
RUP, g/d & 1088 & 745 \\
Metabolizable protein, g/d & 1930 & 1654 \\
$\quad$ From microbial protein & 981 & 563 \\
From undegraded feed & 865 & 85 \\
From endogenous origin & 84 & \\
\hline
\end{tabular}

${ }^{1}$ Calculated using the intake observed during the study with chemical composition of the feed ingredients reported in Table 2.

for the Hi-MP and Lo-MP cows were estimated to be 1732 and $1640 \mathrm{~g} / \mathrm{d}$, respectively (NRC, 2001). Each diet was fed as a TMR in 12 equal meals per day (even h), to minimize postprandial variations, for $35 \mathrm{~d}$. The quantities of diets offered were fixed throughout the experiment and based on the average intake of the $2 \mathrm{wk}$ preceding the start of experiment in order to minimize refusals. The DM of corn silage was determined every week, and TMR offered was adjusted accordingly to insure that the DM offered was constant throughout the study. Orts were recorded daily. Cows had free access to water. One cow had a digestion problem with chopped hay in the TMR (stopped eating and became acidotic) and, instead, received the hay as two daily meals. Cows were milked twice a day, at 0600 and $1800 \mathrm{~h}$, and milk production was recorded at each milking. From d 25 to 31 of each experimental period, milk was sampled at each milking, concomitant with a total collection of urine and feces. The experimental protocol was approved by the Institutional Committee for Animal Care of the Lennoxville Research Centre and animals were cared for according to guidelines of the Canadian Council on Animal Care (1993).

\section{Blood Sampling}

On d 34 or 35 of each experimental period, blood samples were taken simultaneously into heparinized syringes at 30-min intervals for $6 \mathrm{~h}(0900$ to $1500 \mathrm{~h})$ from the arterial, hepatic venous, and portal venous catheters. Portions $(2 \mathrm{ml}$ ) of blood for glucagon analysis 
Table 2. Chemical composition of the feed ingredients of the two diets.

\begin{tabular}{|c|c|c|c|c|c|c|c|c|}
\hline \multirow[b]{2}{*}{$\begin{array}{l}\text { Analyses } \\
(\% \mathrm{DM})\end{array}$} & \multicolumn{8}{|c|}{ Feed ingredients } \\
\hline & $\begin{array}{l}\text { Corn } \\
\text { silage }\end{array}$ & $\begin{array}{l}\text { Grass } \\
\text { hay }\end{array}$ & $\begin{array}{l}\text { Cracked } \\
\text { corn }\end{array}$ & $\begin{array}{l}\text { Soybean } \\
\text { meal }\end{array}$ & $\begin{array}{l}\text { Wheat } \\
\text { distillers }\end{array}$ & $\begin{array}{l}\text { Corn gluten } \\
\text { meal }\end{array}$ & $\begin{array}{l}\text { Canola } \\
\text { meal }\end{array}$ & $\begin{array}{l}\text { Rolled } \\
\text { wheat }\end{array}$ \\
\hline $\mathrm{CP}$ & 8.8 & 14.5 & 10.1 & 52.0 & 36.4 & 70.2 & 37.1 & 15.1 \\
\hline $\mathrm{ADF}$ & 25.4 & 37.8 & 3.0 & 7.7 & 20.6 & 3.9 & 18.1 & 3.6 \\
\hline NDF & 43.3 & 63.4 & 13.0 & 8.0 & 37.6 & 7.2 & 24.7 & 14.3 \\
\hline Lignin & 2.3 & 4.8 & 0.2 & 0.5 & 11.1 & 1.3 & 8.1 & 0.7 \\
\hline ADFIP & 0.2 & 0.9 & 0.2 & 3.1 & 7.8 & 0.4 & 2.2 & 0.2 \\
\hline NDFIP & 1.5 & 5.6 & 1.1 & 0.5 & 9.7 & 2.4 & 3.3 & 1.4 \\
\hline Ash & 4.1 & 7.8 & 1.8 & 6.9 & 5.6 & 3.2 & 8.0 & 2.1 \\
\hline Starch & 28.9 & 1.6 & 69.1 & 9.1 & 3.9 & 14.2 & 7.1 & 59.2 \\
\hline Lipid & 1.6 & 1.0 & 2.1 & 1.5 & 3.3 & 0.4 & 3.1 & 1.2 \\
\hline \multicolumn{9}{|l|}{$\begin{array}{l}\text { Amino acid } \\
\text { (g AA/100g CP) }\end{array}$} \\
\hline Alanine & 6.19 & 5.13 & 7.44 & 4.58 & 3.87 & 9.09 & 4.56 & 3.62 \\
\hline Arginine & 2.52 & 3.94 & 4.82 & 7.97 & 3.80 & 3.21 & 6.17 & 5.18 \\
\hline Aspartate & 5.62 & 8.85 & 7.13 & 12.21 & 5.33 & 6.44 & 7.53 & 5.47 \\
\hline Cysteine & 1.49 & 1.05 & 2.62 & 1.66 & 2.28 & 1.91 & 2.66 & 2.22 \\
\hline Glutamate & 10.78 & 8.57 & 18.45 & 19.26 & 28.18 & 22.90 & 16.78 & 27.74 \\
\hline Glycine & 3.56 & 4.57 & 3.88 & 4.50 & 4.02 & 2.90 & 5.11 & 4.36 \\
\hline Histidine & 1.49 & 1.41 & 2.94 & 2.87 & 2.09 & 2.16 & 2.75 & 2.44 \\
\hline Isoleucine & 2.98 & 3.58 & 3.46 & 4.86 & 3.71 & 4.14 & 4.02 & 3.33 \\
\hline Leucine & 7.80 & 6.32 & 12.26 & 8.13 & 7.11 & 17.02 & 7.04 & 6.66 \\
\hline Lysine & 2.18 & 3.79 & 3.04 & 6.59 & 1.56 & 1.72 & 5.83 & 3.03 \\
\hline Methionine & 1.49 & 1.41 & 2.20 & 1.56 & 1.59 & 2.24 & 2.06 & 1.70 \\
\hline Phenylalanine & 3.67 & 4.22 & 4.61 & 5.25 & 4.64 & 6.32 & 3.96 & 4.59 \\
\hline Proline & 5.16 & 4.22 & 8.28 & 5.47 & 9.66 & 9.20 & 6.02 & 10.13 \\
\hline Serine & 3.67 & 3.65 & 4.93 & 5.42 & 4.61 & 5.60 & 4.44 & 4.66 \\
\hline Threonine & 3.21 & 3.72 & 3.67 & 4.19 & 3.09 & 3.53 & 4.47 & 2.88 \\
\hline Valine & 4.47 & 4.78 & 5.03 & 5.10 & 4.86 & 4.63 & 5.23 & 4.29 \\
\hline Total AA & 66.28 & 69.22 & 94.76 & 99.63 & 90.40 & 103.01 & 88.63 & 92.31 \\
\hline
\end{tabular}

were treated with aprotinin $(500 \mathrm{KIU} / \mathrm{ml}$ of blood, Sigma Chemical Co., St. Louis, MO) at sampling, then centrifuged ( $15 \mathrm{~min}, 1800 \times \mathrm{g}$ at $4^{\circ} \mathrm{C}$ ) and immediately stored at $-20^{\circ} \mathrm{C}$. Plasma was obtained from the remaining blood ( $15 \mathrm{~min}, 1800 \times \mathrm{g}$ at $4^{\circ} \mathrm{C}$ ) and frozen $\left(-20^{\circ} \mathrm{C}\right)$ as soon as possible until subsequent chemical analysis for para-aminohippurate (pAH), somatotropin, insulin, and glucose. Additional blood samples were also collected from the three vessels every hour into either heparinized syringes for measurement of hematocrit, urea nitrogen, ammonia, and $\mathrm{pAH}$ on whole blood and for individual AA on plasma, or into EDTAtreated syringes for analyses of NEFA and IGF-1 on plasma. Hematocrit was determined by microcentrifugation in capillary tubes. To determine blood flow, pAH $(10 \%$ : wt/vol) was infused into a mesenteric vein catheter (Huntington et al., 1989). The infusion $(14.4 \mathrm{~g} / \mathrm{h})$ was preceded by a priming dose $(2 \mathrm{~g})$ and began at least 40 min before the collection of the first blood samples.

\section{Laboratory Analyses}

Samples of feed were lyophilyzed and ground to pass a 1-mm screen. Subsamples of feed were ashed at $550^{\circ} \mathrm{C}$ for $12 \mathrm{~h}$ in a muffle furnace. Feed nitrogen was determined by micro-Kjeldhal analysis. Fiber fractions
(NDF, ADF, and lignin) and $\mathrm{N}$ that is insoluble in neutral detergent and acid detergent were determined on feed samples according to Van Soest et al. (1991). For AA determination, samples of feed were predigested with performic acid to stabilize methionine and cysteine, treated with hydrobromic acid to destroy the performic acid and then were acid-hydrolyzed with $6 \mathrm{~N}$ $\mathrm{HCl}$ (AOAC, 1984), and AA were quantified by ionexchange chromatography (Beckmann 6300, Palo Alto, Ca). A separate acid hydrolysis $(6 \mathrm{HCl})$ digestion procedure, was conducted for Phe, Tyr, and His, because those AA are destroyed during the oxidation process and by reaction with bromine.

Nitrogen content of milk (protein $=\mathrm{N} \times 6.38$ ) was determined by micro-Kjeldahl method (AOAC, 1984). Milk fat was measured by according to Roese-Gottlieb method (AOAC, 1984) and lactose with a commercial kit (Boehringer Mannheim, \#176 303). The AA concentrations were determined after deproteinization of 1 $\mathrm{ml}$ of plasma with $25 \mathrm{mg}$ of sulfosalicylic acid by ionexchange chromatography, with ninhydrin as the colorimetric reagent (LKB 4400 Amino Acid Analyser, LKB Biochrom Ltd, Cambridge, UK). Two branched-chain AA (BCAA), leucine and valine, were analyzed with the isotopic dilution technique, using as the internal 
standard a $\left[\mathrm{U}_{-}{ }^{13} \mathrm{C}\right]$ AA mixture obtained from hydrolysis of algal protein (Calder et al., 1999).

Concentrations of urea, ammonia, and pAH were determined by colorimetric methods described previously (Huntington, 1984; Reynolds et al., 1989) with a Technicon analyzer (Technicon Autoanalyzer II, Technicon Instruments Corporation, Tarrytown, NY) within $2 \mathrm{~h}$ of sampling. Glucose concentrations were analyzed using colorimetric kits from Boehringer Mannheim (Dorval, QC, Canada). Nonesterified fatty acid concentrations were also measured by an enzymatic procedure with a commercial kit (\# 990-75401, Wako Chemicals, Dallas, TX), as described by McCutcheon and Bauman (1986). Double-antibody radioimmunoassays were used to determine concentrations of insulin, somatotropin, IGF1, and glucagon (Lapierre et al. 2000a, 2000b). The concentrations of IGF-1 and somatotropin were only performed on arterial samples. Sensitivity (10\% displacement) for the insulin, somatotropin, IGF-1, and glucagon assays averaged 12.5, 200, 6.25, and $2.5 \mathrm{pg}$, respectively. Intraassay and interassay coefficients of variation were, respectively, 11.9 and $10.4 \%$ for insulin, $<1$ and $13.8 \%$ for somatotropin, 4.8 and $2.0 \%$ for IGF1 , and 16.0 and $<1 \%$ for glucagon. All samples from each animal were analyzed at the same time to remove interassay variation from treatment comparisons.

\section{Calculations and Statistical Analysis}

Data used for statistical analyses for milk production and composition are the average of measurements made from d 25 to 31 . Blood and plasma flow were calculated from downstream dilution of pAH infused into mesenteric catheters (Katz and Bergman, 1969). Daily averages for blood and plasma flows were used to calculate net fluxes of nutrients and hormones. If, within one sampling day, the CV of the mean plasma or blood flows for an animal were higher than $15 \%$ due to only one sample, then this value was removed. Net fluxes for the PDV, liver, and TSP (PDV plus liver) tissues were calculated for each cow as the product of the average venous-arterial (VA) concentration difference measured on each sampling day $\times$ the average blood or plasma flow measured on the same day. A negative net flux indicates net removal, or utilization, from blood or plasma, whereas a positive net flux indicates net production, or release. The ratio of hepatic net removal on net portal absorption of AA was calculated as: net liver flux/net PDV flux for each cow.

Data were analyzed statistically according to the crossover design, using the GLM procedure of SAS (1985) with treatment, period, and cow as the main effects. Student's $t$ tests were used to test whether VA differences were different from zero. Treatment differ- ences were considered significant if $P<0.10$ and as a tendency between $0.10<P<0.20$.

\section{RESULTS}

\section{Milk Production and Intake}

Milk yield was greater $(P=0.08)$ for Hi-MP than Lo-MP, with milk composition only altered for lactose concentration, which tended $(P=0.19)$ to increase with the Hi-MP diet (Table 3). This increased $(P \leq 0.08)$ protein and lactose yields or tended to increase $(P=$ 0.11) fat yield, for the Hi-MP diet. The DMI did not differ $(P>0.20)$ between the two diets and averaged 17.9 vs. $18.1 \pm 0.27 \mathrm{~kg} / \mathrm{d}$ for the Hi-MP vs. Lo-MP diets, respectively.

\section{Nitrogen Compounds}

Neither blood nor plasma flows through the PDV and liver (Table 4$)$ were affected $(P>0.20)$ by dietary treatment. Arterial concentrations and net fluxes across the splanchnic tissues of individual AA are presented in Tables 5 and 6. Arterial total AA (TAA) concentrations were not different between the two diets, nor were the summations of essential (EAA) or nonessential AA (NEAA). On an individual basis, however, concentrations of leucine were greater $(P<0.01)$ when cows received the Hi-MP diet, compared with the Lo-MP diet. This contributed to the higher $(P=0.07)$ BCAA concentrations. Conversely, lysine concentrations were greater $(P=0.05)$ in cows fed the Lo-MP diet. The concentrations of all other EAA were not affected by the diet. In contrast, the concentrations of four NEAA, (alanine, arginine, glutamate: $P=0.04$ ) were or tended to be (glutamine: $P<0.11$ ) greater when cows received the Lo-MP diet. The VA differences for all AA were different from zero (data not shown), except for the BCAA and proline (hepatic-portal differences), and glutamine plus glycine (hepatic-arterial differences).

Net PDV release of TAA $(P=0.09)$, EAA $(P=0.07)$, or BCAA $(P=0.01)$ were or tended (NEAA: $P=0.11)$ to be greater with the Hi-MP diet. These values reflected a numerical trend for most individual AA, but with only alanine, leucine, methionine, and threonine being significant $(P<0.10)$. Lysine absorption tended to be higher $(P=0.13)$ for the Lo-MP diet, in line with the increased arterial concentration. Net hepatic flux of AA was, in general, not affected by diet. This resulted in a tendency for increased net splanchnic release for both TAA $(P=0.15)$ and EAA $(P=0.12)$. On an individual basis, glutamine, isoleucine, leucine, methionine, and threonine were released to a greater $(P<0.10)$ extent from the splanchnic tissues with the Hi-MP diet compared with the Lo-MP diet. The ratio of the net hepatic 
Table 3. Effect of the supply of metabolizable protein (MP) on milk yield and composition in late-lactation Holstein cows. ${ }^{1}$

\begin{tabular}{|c|c|c|c|c|}
\hline \multirow[b]{2}{*}{ Milk } & \multicolumn{2}{|c|}{ Treatments } & \multirow[b]{2}{*}{ SEM } & \multirow[b]{2}{*}{$P^{2}$} \\
\hline & High MP & Low MP & & \\
\hline Production, kg/d & 17.7 & 15.9 & 0.5 & 0.08 \\
\hline Protein yield, g/d & 717 & 653 & 17 & 0.07 \\
\hline Protein concentration, $\%$ & 4.54 & 4.64 & 0.07 & 0.41 \\
\hline Fat yield, g/d & 794 & 727 & 23 & 0.11 \\
\hline Fat concentration, $\%$ & 4.08 & 4.14 & 0.04 & 0.44 \\
\hline Lactose yield, g/d & 696 & 600 & 28 & 0.08 \\
\hline Lactose concentration, \% & 3.91 & 3.75 & 0.07 & 0.19 \\
\hline
\end{tabular}

${ }^{1}$ Least squares means presented with pooled SEM, $\mathrm{n}=6$.

${ }^{2}$ Probability corresponding to the null hypothesis.

Table 4. Effect of the supply of metabolizable protein (MP) on plasma and blood flow (L/h) across the splanchnic tissues in late-lactation Holstein cows. ${ }^{1}$

\begin{tabular}{llllll}
\hline & & \multicolumn{2}{c}{ Treatments } & \\
\cline { 3 - 4 } Fluid & Tissue $^{2}$ & High MP & Low MP & SEM & $P^{3}$ \\
\hline Plasma & PDV & 1193 & 1230 & 37 & 0.51 \\
& TSP & 1419 & 1426 & 24 & 0.86 \\
Blood & PDV & 1677 & 1618 & 78 & 0.62 \\
& TSP & 1952 & 1884 & 81 & 0.59 \\
\hline
\end{tabular}

${ }^{1}$ Least squares means presented with pooled SEM, $\mathrm{n}=6$.

${ }^{2} \mathrm{PDV}$ : portal-drained viscera; TSP: total splanchnic tissues.

${ }^{3}$ Probability corresponding to the null hypothesis.

Table 5. Effect of the supply of metabolizable protein (MP) on plasma arterial concentrations of amino acids $(\mu M)$ in late-lactation Holstein cows. ${ }^{1}$

\begin{tabular}{|c|c|c|c|c|}
\hline \multirow[b]{2}{*}{ Amino acid ${ }^{2}$} & \multicolumn{2}{|c|}{ Treatments } & \multirow[b]{2}{*}{ SEM } & \multirow[b]{2}{*}{$P^{3}$} \\
\hline & High MP & Low MP & & \\
\hline TAA & 1706 & 1785 & 81 & 0.54 \\
\hline EAA & 877 & 845 & 33 & 0.53 \\
\hline NEAA & 829 & 940 & 47 & 0.18 \\
\hline BCAA & 592 & 532 & 17 & 0.07 \\
\hline Alanine & 186 & 211 & 6 & 0.04 \\
\hline Arginine & 59 & 67 & 2 & 0.06 \\
\hline Aspartate & 24 & 26 & 2 & 0.40 \\
\hline Citrulline & 67 & 65 & 3 & 0.76 \\
\hline Glutamate & 138 & 153 & 4 & 0.07 \\
\hline Glutamine & 41 & 62 & 7 & 0.108 \\
\hline Glycine & 153 & 183 & 12 & 0.17 \\
\hline Histidine & 31 & 28 & 3 & 0.50 \\
\hline Isoleucine & 107 & 115 & 7 & 0.53 \\
\hline Leucine & 216 & 164 & 3 & 0.001 \\
\hline Lysine & 67 & 84 & 4 & 0.05 \\
\hline Methionine & 11 & 14 & 1 & 0.21 \\
\hline Ornithine & 66 & 73 & 4 & 0.35 \\
\hline Phenylalanine & 43 & 38 & 2 & 0.25 \\
\hline Proline & 178 & 191 & 21 & 0.68 \\
\hline Serine & 67 & 72 & 4 & 0.38 \\
\hline Taurine & 16 & 16 & $<1$ & 0.69 \\
\hline Threonine & 74 & 83 & 4 & 0.23 \\
\hline Tyrosine & 45 & 41 & 3 & 0.48 \\
\hline Valine & 269 & 253 & 7 & 0.23 \\
\hline
\end{tabular}

${ }^{1}$ Least squares means presented with pooled SEM, $\mathrm{n}=6$.

${ }^{2}$ TAA: total amino acids (AA); EAA: essential AA; NEAA: non essential AA; BCAA: branched-chain AA.

${ }^{3}$ Probability corresponding to the null hypothesis. 
Table 6. Effect of the supply of metabolizable protein (MP) on splanchnic net fluxes of amino acids (mmol/ h) in late-lactation Holstein cows. ${ }^{1}$

\begin{tabular}{|c|c|c|c|c|c|}
\hline \multirow[b]{2}{*}{ Amino acid $^{2}$} & \multirow[b]{2}{*}{ Tissue $^{3}$} & \multicolumn{2}{|c|}{ Treatments } & \multirow[b]{2}{*}{ SEM } & \multirow[b]{2}{*}{$P^{4}$} \\
\hline & & High MP & Low MP & & \\
\hline \multirow[t]{3}{*}{ TAA } & PDV & 489 & 389 & 30.3 & 0.09 \\
\hline & Liver & -113 & -128 & 27.8 & 0.70 \\
\hline & TSP & 376 & 261 & 46.0 & 0.15 \\
\hline \multirow[t]{3}{*}{ EAA } & PDV & 204 & 181 & 5.9 & 0.07 \\
\hline & Liver & -10 & -21 & 7.6 & 0.33 \\
\hline & TSP & 194 & 160 & 12.0 & 0.12 \\
\hline \multirow[t]{3}{*}{ NEAA } & PDV & 285 & 208 & 26.4 & 0.108 \\
\hline & Liver & -103 & -107 & 21.7 & 0.90 \\
\hline & TSP & 182 & 101 & 37.4 & 0.20 \\
\hline \multirow[t]{3}{*}{ BCAA } & PDV & 90 & 74 & 1.6 & 0.01 \\
\hline & Liver & 20 & 13 & 3.4 & 0.15 \\
\hline & TSP & 110 & 87 & 3.2 & 0.01 \\
\hline \multirow[t]{3}{*}{ Alanine } & PDV & 91.5 & 71.0 & 6.05 & 0.08 \\
\hline & Liver & -45.8 & -43.9 & 8.68 & 0.89 \\
\hline & TSP & 45.7 & 27.1 & 14.27 & 0.41 \\
\hline \multirow[t]{3}{*}{ Arginine } & PDV & 18.4 & 19.7 & 1.60 & 0.59 \\
\hline & Liver & -8.2 & -9.9 & 1.39 & 0.41 \\
\hline & TSP & 10.2 & 9.8 & 1.59 & 0.85 \\
\hline \multirow[t]{3}{*}{ Aspartate } & PDV & 12.6 & 10.9 & 1.02 & 0.30 \\
\hline & Liver & -3.9 & -4.6 & 1.36 & 0.73 \\
\hline & TSP & 8.7 & 6.3 & 1.85 & 0.40 \\
\hline \multirow{3}{*}{ Citrulline } & PDV & 8 & 10.8 & 1.45 & 0.24 \\
\hline & Liver & 3.9 & -0.5 & 2.69 & 0.32 \\
\hline & TSP & 11.9 & 10.3 & 1.35 & 0.48 \\
\hline \multirow[t]{3}{*}{ Glutamate } & PDV & 14.5 & 4.6 & 3.33 & 0.11 \\
\hline & Liver & 24.3 & 31.5 & 3.48 & 0.22 \\
\hline & TSP & 38.9 & 36.1 & 3.84 & 0.64 \\
\hline Glutamine & PDV & 10.2 & 2.2 & 2.87 & 0.12 \\
\hline & Liver & -1.7 & -7.7 & 3.12 & 0.25 \\
\hline & TSP & 8.5 & -5.5 & 2.04 & 0.01 \\
\hline Glycine & PDV & 44.6 & 41.7 & 2.55 & 0.48 \\
\hline & Liver & -34.1 & -44.5 & 3.20 & 0.09 \\
\hline & TSP & 10.5 & -2.8 & 4.69 & 0.12 \\
\hline Histidine & PDV & 8.8 & 6.3 & 0.98 & 0.16 \\
\hline & Liver & -1.7 & -1.5 & 1.09 & 0.92 \\
\hline & TSP & 7.1 & 4.8 & 1.64 & 0.39 \\
\hline Isoleucine & PDV & 26.2 & 20.7 & 2.11 & 0.14 \\
\hline & Liver & 6.5 & 4.3 & 0.59 & 0.06 \\
\hline & TSP & 32.7 & 24.9 & 2.45 & 0.09 \\
\hline Leucine & PDV & 37.4 & 29.8 & 1.02 & 0.007 \\
\hline & Liver & 6.3 & 2.6 & 2.19 & 0.31 \\
\hline & TSP & 43.7 & 32.4 & 1.65 & 0.009 \\
\hline Lysine & PDV & 29.2 & 34.1 & 1.78 & 0.13 \\
\hline & Liver & -1.3 & -3.5 & 4.59 & 0.76 \\
\hline & TSP & 27.9 & 30.6 & 5.84 & 0.76 \\
\hline Methionine & PDV & 9.7 & 5.9 & 0.40 & 0.003 \\
\hline & Liver & -4.2 & -4.1 & 1.29 & 0.96 \\
\hline & TSP & 5.5 & 1.8 & 1.07 & 0.07 \\
\hline Ornithine & PDV & 15.0 & 18.2 & 1.33 & 0.18 \\
\hline & Liver & 8.9 & 0.5 & 3.01 & 0.12 \\
\hline & TSP & 23.9 & 18.7 & 3.27 & 0.33 \\
\hline Phenylalanine & PDV & 21.2 & 20.5 & 1.54 & 0.74 \\
\hline & Liver & -10.8 & -10.9 & 1.69 & 0.99 \\
\hline & TSP & 10.4 & 9.6 & 1.41 & 0.70 \\
\hline Proline & PDV & 59.6 & 32.5 & 1.76 & 0.35 \\
\hline & Liver & -7.3 & -9.9 & 8.37 & 0.84 \\
\hline & TSP & 51.7 & 22.6 & 1.99 & 0.36 \\
\hline Serine & PDV & 34.7 & 29.4 & 2.23 & 0.18 \\
\hline & Liver & -25.8 & -21.1 & 2.13 & 0.20 \\
\hline & TSP & 8.9 & 8.3 & 3.48 & 0.90 \\
\hline Taurine & PDV & 3.8 & 2.5 & 1.79 & 0.65 \\
\hline & Liver & -1.5 & -2.2 & 0.71 & 0.52 \\
\hline & TSP & 2.3 & 0.3 & 1.90 & $\begin{array}{l}0.51 \\
\text { continued }\end{array}$ \\
\hline
\end{tabular}


Table 6 (continued). Effect of the supply of metabolizable protein (MP) on splanchnic net fluxes of amino acids $(\mathrm{mmol} / \mathrm{h})$ in late-lactation Holstein cows. ${ }^{1}$

\begin{tabular}{llllll}
\hline \multirow{2}{*}{ Amino acid $^{2}$} & \multicolumn{3}{c}{ Treatments } & & \\
\cline { 3 - 4 } Threonine & Tissue $^{3}$ & High MP & Low MP & SEM & $P^{4}$ \\
& PDV & 26.6 & 20.5 & 1.51 & 0.053 \\
\multirow{2}{*}{ Tyrosine } & Liver & -3.8 & -3.4 & 1.31 & 0.84 \\
& TSP & 22.8 & 17.1 & 1.52 & 0.055 \\
Valine & PDV & 17.3 & 15.5 & 1.07 & 0.31 \\
& Liver & -9 & -7.2 & 1.31 & 0.39 \\
& TSP & 8.3 & 8.4 & 1.32 & 0.99 \\
& PDV & 26.3 & 23.6 & 0.93 & 0.11 \\
& Liver & 7.6 & 5.5 & 1.88 & 0.48 \\
\hline
\end{tabular}

${ }^{1}$ Least squares means presented with pooled SEM, $\mathrm{n}=6$.

${ }^{2}$ TAA: total amino acids (AA); EAA: essential AA; NEAA: non essential AA; BCAA: branched-chain AA. ${ }^{3} \mathrm{PDV}$ : portal-drained viscera; TSP: total splanchnic tissue.

${ }^{4}$ Probability corresponding to the null hypothesis.

flux on net PDV release was not affected by the diet for the EAA but glycine extraction increased $(P=0.07)$ with the Hi-MP diet (Table 7).

All VA concentration differences of $\mathrm{NH}_{3}-\mathrm{N}$ were affected $(P<0.05)$ by the diet (data not shown), with both portal-arterial and hepatic-portal differences greater for the Lo-MP diet. Despite this, only TSP $\mathrm{NH}_{3}-\mathrm{N}$ flux tended $(P=0.11)$ to be greater for the Lo-MP compared with the Hi-MP diet (Table 8). Arterial urea concentrations were higher $(P=0.09)$ for cows fed the Lo-MP (Table 8), but neither VA concentration differences (data not shown) nor net urea flux across splanchnic tissues were affected $(P>0.20)$ by the diet.

\section{Metabolites and Hormones}

Arterial concentrations and net fluxes of glucose were not different $(P>0.20)$ between the two diets (Tables
8 and 9). Net glucose flux was positive across the TSP, but near zero across the PDV for both treatments (Table $9)$. The diet had no effect $(P>0.20)$ on arterial concentration of NEFA (Table 8), but both portal flux and hepatic removal tended to increase $(P<0.18)$ with the Lo-MP diet (Table 9).

Arterial concentrations (Table 8) and net fluxes of insulin (Table 9$)$ were not affected $(P>0.20)$ by the diets. Similarly, arterial concentration of glucagon did not differ $(P>0.20)$ between diets (Table 8$)$, but hepatic removal of glucagon increased $(P=0.04)$ with the LoMP diet, while PDV and TSP fluxes were unaffected $(P$ $>0.20$; Table 9). Hepatic removal of glucagon relative to portal absorption increased $(P=0.09)$ for the Lo-MP diet, averaging 0.20 vs. $0.38 \pm 0.038$ for the Hi-MP vs. Lo-MP diet, respectively. Glucagon results from one cow were not used in calculations because of radioimmunoassay problems; then $\mathrm{n}=5$ for both treatments.

Table 7. Effect of the supply of metabolizable protein (MP) on the ratio of hepatic net removal of amino acids relative to portal absorption. ${ }^{1}$

\begin{tabular}{lllll}
\hline & \multicolumn{2}{c}{ Treatments } & \\
\cline { 2 - 3 } Amino acid & High MP & Low MP & SEM & $P^{2}$ \\
\hline Alanine & 0.56 & 0.57 & 0.058 & 0.95 \\
Arginine & 0.40 & 0.46 & 0.041 & 0.39 \\
Aspartate & 0.20 & 0.31 & 0.099 & 0.46 \\
Glycine & 0.83 & 0.11 & 0.071 & 0.07 \\
Histidine & 0.16 & 0.26 & 0.204 & 0.73 \\
Lysine & 0.04 & 0.06 & 0.14 & 0.93 \\
Methionine & 0.39 & 0.73 & 0.171 & 0.23 \\
Phenylalanine & 0.52 & 0.50 & 0.038 & 0.29 \\
Proline & 0.11 & 0.75 & 0.371 & 0.66 \\
Serine & 0.80 & 0.72 & 0.112 & 0.64 \\
Threonine & 0.12 & 0.18 & 0.078 & 0.17 \\
Tyrosine & 0.56 & 0.45 & 0.045 & \\
\hline
\end{tabular}

${ }^{1}$ Least squares means presented with pooled SEM, $\mathrm{n}=6$; calculated as net liver flux / net portal-drained viscera flux; extraction of the branched-chain amino acids are not reported as the net liver flux was positive.

${ }^{2}$ Probability corresponding to the null hypothesis. 
Table 8. Effect of the supply of metabolizable protein (MP) on arterial concentrations of metabolites and hormones in lactating dairy cows. ${ }^{1}$

\begin{tabular}{lcccc}
\hline & \multicolumn{2}{c}{ Treatments } & & \\
\cline { 2 - 3 } Item & High MP & Low MP & SEM & $P^{2}$ \\
\hline Blood & & & & \\
$\quad$ Ammonia-N, mM & 0.15 & 0.15 & 0.009 & 0.5 \\
Urea-N, mM & 9.1 & 10.9 & 0.53 & 0.09 \\
Plasma & & & 0.019 & 0.96 \\
Glucose, mM & 3.67 & 3.67 & 11.35 & 0.73 \\
NEFA, meq/l & 129.4 & 123.4 & 0.099 & 0.82 \\
Insulin, ng/ml & 0.97 & 1.00 & 0.017 & 0.36 \\
Glucagon, ng/ml & 0.25 & 1.6 & 0.10 & 0.29 \\
Somatotropin, ng/ml & 1.7 & 127.9 & 5.24 & 0.74 \\
IGF-I, ng/ml & 125.3 & & & \\
\hline
\end{tabular}

${ }^{1}$ Least squares means presented with pooled SEM, $\mathrm{n}=6$, except for glucagons where $\mathrm{n}=5$.

${ }^{2}$ Probability corresponding to the null hypothesis.

Arterial somatotropin and IGF-1 concentrations were not affected $(P>0.20)$ by the treatment and averaged 1.7 vs. $1.6 \pm 0.10 \mathrm{ng} / \mathrm{ml}$ and $125 \mathrm{vs.} 128 \pm 5.2 \mathrm{ng} / \mathrm{ml}$ for the Hi-MP and Lo-MP diets, respectively (Table 8).

\section{DISCUSSION}

\section{Blood Flows}

Portal blood flow averaged $86 \%$ of total liver blood flow. This agrees with previous studies in lactating dairy cows, where the contribution of portal flow to splanchnic flow ranged from 75 to 85\% (Reynolds et al., 1988a; De Visser et al., 1997; Bach et al., 2000). In lactating dairy cows, increasing the $\mathrm{CP}$ content of the diet from 15 to $18 \%$ did not affect splanchnic blood flows (Bach et al., 2000). Similarly, in nonlactating dairy cows, acute AA infusions into the mesenteric vein, up to $5 \times$ basal absorption, did not alter splanchnic blood flows (Wray-Cahen et al., 1997), nor did postruminal casein infusion in growing cattle (Guerino et al., 1991a).

Table 9. Effect of the supply of metabolizable protein (MP) on splanchnic net fluxes of metabolites and hormones in late-lactation Holstein cows. ${ }^{1}$

\begin{tabular}{|c|c|c|c|c|c|}
\hline \multirow[b]{2}{*}{ Item } & \multirow[b]{2}{*}{ Tissue $^{2}$} & \multicolumn{2}{|c|}{ Treatments } & \multirow[b]{2}{*}{ SEM } & \multirow[b]{2}{*}{$P^{3}$} \\
\hline & & High MP & Low MP & & \\
\hline \multicolumn{6}{|l|}{ Blood } \\
\hline \multirow[t]{3}{*}{ Ammonia-N, mmol/h } & PDV & 504 & 594 & 47.5 & 0.25 \\
\hline & Liver & -512 & -597 & 47.6 & 0.28 \\
\hline & TSP & -8 & -3 & 2.1 & 0.11 \\
\hline \multirow[t]{3}{*}{ Urea-N, mmol/h } & $\mathrm{PDV}$ & -212 & -177 & 90.9 & 0.80 \\
\hline & Liver & 973 & 924 & 72.9 & 0.66 \\
\hline & TSP & 761 & 747 & 75.5 & 0.91 \\
\hline \multicolumn{6}{|l|}{ Plasma } \\
\hline \multirow{3}{*}{ TAA-N ${ }^{4}, \mathrm{mmol} / \mathrm{h}$} & PDV & 614 & 508 & 35.7 & 0.108 \\
\hline & Liver & -148 & -177 & 38.9 & 0.62 \\
\hline & TSP & 466 & 331 & 58.9 & 0.19 \\
\hline \multirow[t]{3}{*}{ Glucose, $\mathrm{mmol} / \mathrm{h}$} & PDV & 22 & 4 & 11.5 & 0.33 \\
\hline & Liver & 583 & 580 & 25.9 & 0.93 \\
\hline & TSP & 606 & 584 & 27.0 & 0.58 \\
\hline \multirow[t]{3}{*}{ NEFA, meq/h } & PDV & 6.3 & 16.9 & 4.52 & 0.18 \\
\hline & Liver & -25.6 & -34.6 & 3.22 & 0.12 \\
\hline & TSP & -21.3 & -17.7 & 4.38 & 0.60 \\
\hline \multirow[t]{3}{*}{ Insulin, $\mu \mathrm{g} / \mathrm{h}$} & PDV & 391 & 424 & 87.2 & 0.81 \\
\hline & Liver & -148 & -194 & 50.2 & 0.56 \\
\hline & TSP & 243 & 232 & 44.9 & 0.87 \\
\hline \multirow[t]{3}{*}{ Glucagon, $\mu \mathrm{g} / \mathrm{h}$} & PDV & 50 & 49 & 2.5 & 0.93 \\
\hline & Liver & -10 & -19 & 1.7 & 0.04 \\
\hline & TSP & 40 & 31 & 4.0 & 0.22 \\
\hline
\end{tabular}

${ }^{1}$ Least squares means presented with pooled SEM, $\mathrm{n}=6$, except for glucagons where $\mathrm{n}=5$.

${ }^{2} \mathrm{PDV}$ : portal-drained viscera; TSP: total splanchnic tissue.

${ }^{3}$ Probability corresponding to the null hypothesis.

${ }^{4}$ TAA-N: nitrogen from total amino acids, from Table 5. 
Although MP supply increased with the Hi-MP diet, both diets provided similar metabolizable energy. This probably explains why plasma and blood flows were not affected by treatments, as these are controlled by energy rather than protein supply (Huntington, 1990).

\section{Nitrogen Compounds}

From estimations with the NRC model (NRC, 2001), decreasing protein rumen degradability from 75 to $62 \%$, from the Lo-MP to the Hi-MP diet, increased supply of MP through an increment of RUP. The supply of MP from bacterial synthesis was not negatively affected at the lower protein degradability, as RDP supply met the requirement for the Hi-MP diet (1818 vs. $1803 \mathrm{~g} / \mathrm{d}$ ) and exceeded it for the Lo-MP diet (2206 vs. $1850 \mathrm{~g} / \mathrm{d}$ ). Therefore, for a similar CP intake, the estimated higher supply of MP (NRC, 2001) increased milk volume and milk protein yields. In this study, the recovery of the predicted increment in MP supply into extra milk protein averaged $22.5 \%$. This is similar to the mean recovery $(21 \%)$ into milk protein of casein infusions into the abomasum reviewed by Hanigan et al. (1998). As those authors mentioned, it is probable that using a fixed factor for the efficiency of conversion of MP into milk protein until requirements are met does not reflect true biology response, rather a curvilinear approach would be closer to reality.

Based on the NRC (2001) model, the Hi-MP diet increased MP through an increment in RUP. Increasing RUP has an inconsistent effect on milk production (Santos et al., 1998), and positive results are only to be expected when such a supplementation does not have a deleterious effect on microbial protein synthesis and has an overall favorable influence on duodenal AA flow. This was probably the case in our study, as supported by the observed additional net absorption of total AA into the portal vein. For cows in early lactation, improving the profile of AA at a constant RUP supply, increased the PDV appearance only of methionine, while raising the $\mathrm{CP}$ content of the diet improved absorption of histidine, isoleucine, and methionine (Bach et al., 2000). Diets containing four different protein sources, where undegradable-protein (determined in vitro) ranged from 16 to $69 \%$ of total $\mathrm{CP}$ intake, did not alter portal absorption of $\alpha$-amino-N in beef heifers (Huntington, 1987), although estimated MP supply (NRC, 2001) increased from high to low undegradable N. In contrast, for beef steers fed a similar CP diet, net $\alpha$ amino-N absorption was enhanced by almost $50 \%$ when metabolizable energy intake was increased (Reynolds et al., 1992). Together, these results indicate that CP or RUP supply cannot be used as the sole indicators of the protein quality of a diet, as the energy source can have a major impact on microbial protein synthesis and, therefore, on the total duodenal protein flow.

The proportion of $\mathrm{N}$ absorbed in the portal vein as AA-N to apparent $\mathrm{N}$ digested (Lapierre et al., 2002) was greater for the Hi-MP compared with the Lo-MP $\operatorname{diet}(0.67$ vs. $0.51 \pm 0.046, P=0.07)$. This supports the concept of greater availability of dietary $\mathrm{N}$ as absorbable AA-N from the Hi-MP diet. The 0.67 value is much greater than the 0.50 reported for $\alpha$-amino- $\mathrm{N}$ absorption to $\mathrm{N}$ digested in other dairy cow studies (Huntington, 1984; Reynolds et al., 1988a) and for the 0.39 observed across a wide range of studies with growing cattle (Lapierre and Lobley, 2001). The causes of these wide differences reported in the literature may be twofold. First, measurements of individual AA rather than $\alpha$-amino-N yield higher and more reliable values (Lapierre and Lobley, 2001). Second, perhaps the diets fed to growing cattle were not as well balanced as those for lactating dairy cows. The increment in AA portal absorption in cows fed the Hi-MP diet, compared with the Lo-MP, was approximately 0.78 of the extra-predicted MP.

The lower net AA absorption with the Lo-MP diet contrasts with a greater apparent $\mathrm{N}$ digestibility compared with the Hi-MP diet (337 vs. $303 \mathrm{~g}$ of digested N per day, respectively; Lapierre et al., 2002). The increase in digested $\mathrm{N}$ for the Lo-MP diet reflects $\mathrm{N}$ disappearance from the gut in forms other than AA, probably ammonia. Indeed, portal absorption of $\mathrm{NH}_{3}$ was higher, and the ratio of portal absorption of $\mathrm{NH}_{3}: \mathrm{AA}-\mathrm{N}$ was markedly affected by the diets $(0.91$ vs. $1.30 \pm 0.094$, Hi-MP vs. Lo-MP diet; $P=0.05$ ). While this ratio averaged 0.90 , in other dairy cow studies, the range was considerable (0.50 to 1.29; Huntington, 1984; Reynolds et al., 1988a; McGuire et al., 1989; Bach et al., 2000). The type of diet, linked to the nitrogen vs. energy availability in the rumen, would impact on this ratio, as shown by the ratios observed with growing cattle fed either concentrates (1.05) or forage-based (2.59) diets (Lapierre and Lobley, 2001).

Diet effects may also explain the low values for the amount of urea-N that was returned to the gut. For both diets, the PDV urea flux, that represents the urea$\mathrm{N}$ recycled to the gut except for saliva, averaged 0.20 of the apparent digested N. This is lower than the 0.44 observed by Huntington (1984) and Reynolds et al. (1988) in cows fed corn silage plus supplement, but is in within the range reported by Casse et al. (1994) for cows offered alfalfa hay and concentrates. Assuming a similar total gut entry rate of urea with both types of diets, these comparisons suggest that, in animals fed dry hay, the recycling of urea through the saliva may represent a higher contribution to gut entry rate. 
In some studies, when AA supply was increased through abomasal or mesenteric infusion, net hepatic removal of AA was increased equivalent to the amount infused leaving; as a result, no increment in the net supply to peripheral tissues (Guerino et al., 1991a; Bruckental et al., 1997; Wray-Cahen et al., 1997). When the demand of peripheral tissues was increased by somatotropin administration, however, the hepatic removal of AA during AA abomasal casein infusion decreased to the level observed during the precasein control period (Bruckental et al., 1997). This allowed additional delivery of AA to the periphery to support the anabolic response to somatotropin. Similarly, in the present study, although increased portal absorption of AA occurred with the Hi-MP diet, hepatic extraction of AA was not altered. As a consequence, postliver supply of AA to the peripheral tissues was improved and supported the increased milk protein output. Hepatic removal of AA can be viewed as the sum of obligate hepatic needs (e.g., basal urea production, plasma protein synthesis) plus extraction of AA not needed to support peripheral tissue anabolism. Thus, in high-production animals, a greater fraction of absorbed AA should avoid hepatic removal. Indeed, and even though milk yield was only $17 \mathrm{~kg} / \mathrm{d}$, only $28 \%$ of total AA absorbed were extracted by the liver in the current study, comparable with values reported for rapidly growing cattle (18 to 30\%: Bruckental et al., 1997; Lapierre et al., 2000). These data contrast with higher proportional extractions in slower-growing cattle (55 to 58\%: Koeln et al., 1993; Bruckental et al., 1997) or nonlactating dairy cows (43\%: Wray-Cahen et al., 1997). Fractional hepatic extractions should not be seen, therefore, as 'absolutes' but reflect the relationship between the demand of peripheral tissues and the amount absorbed. Large fractional extractions, however, have also been reported for high-producing animals. In early-lactation Holstein cows averaging $46 \mathrm{~kg} / \mathrm{d}$, hepatic removal of total AA averaged $61 \%$ of portal absorption (Bach et al., 2000). However, the ratios observed in this last study might not reflect daily means as blood samples were collected 3,6 , and $12 \mathrm{~h}$ after one of the two daily meals. Averaging these flows on a daily basis yielded a postliver supply of EAA insufficient to account for EAA milk output, which would imply a too large contribution of AA from mobilization of body protein, if sustained constant during the whole day.

Overall, the BCAA had the lowest hepatic removal, the net fluxes were even positive in the current study, as previously reported (Wray-Cahen et al., 1997; Bach et al., 2000); this may reflect hepatic extraction and utilization of peptides and proteins, including hormone (see later). The fractional extractions (the ratios of net hepatic on PDV fluxes) of the other EAA increased in the order lysine, threonine, and histidine, methionine, and phenylalanine, comparable to data from other reports (e.g., Wray-Cahen et al., 1997). Again, these values should not be considered as fixed but reflect the relationship between absorption, liver metabolism, requirements for milk protein synthesis, and the extent to which extra-hepatic tissue sites can catabolize the individual AA. Thus, although the estimated AA output in milk protein represented $0.63,0.52,0.60,0.49,0.68$, $0.38,0.42$, and 0.61 of portal net flux for histidine, isoleucine, leucine, lysine, methionine, phenylalanine, threonine, and valine, respectively, these values were $0.81,0.42,0.54,0.52,1.80,0.80,0.49$, and 0.48 when splanchnic net flux was used for comparison. The first set of values represent the gross efficiency of utilization of absorbed AA for milk protein synthesis. The second values reflect the differences in hepatic extraction for the various individual AA. If the liver were the only site of catabolism of the EAA and the only anabolic fate was for milk protein synthesis (no tissue $\mathrm{N}$ retention), then the milk protein output to net TSP supply should be unity. In practice, this was the case only for histidine and phenylalanine (the mean values are not significantly different from unity). For the other AA, more was available beyond the liver than needed to support milk protein synthesis and, therefore, this implies that catabolism or utilization of these occurs in nonhepatic tissues. The BCAA can be oxidized in a variety of extrahepatic tissues (Goodwin et al., 1987), including the mammary gland (Bequette et al., 1996; Thivierge et al., 2002). Threonine is catabolised by the pancreas (Le Floc'h et al., 1997) and, more lysine is extracted by the mammary gland than is secreted in milk protein (e.g., Guinard and Rulquin, 1994), indicative of catabolism within the udder. Methionine is probably in the same category as phenylalanine and histidine, with the majority of catabolism restricted to the liver and, therefore, with a net TSP flux reflecting output in milk protein, although the data have greater variance, associated with the problems of measuring VA differences at low concentrations.

The questions arising from these observations are: "Does the liver control peripheral delivery of these EAA and, therefore, milk protein output or does the mammary gland uses what it needs to fulfill its anabolic ability and then the liver catabolizes any excess to avoid toxicity?" and, if the latter mechanism operates, "What are the signals coordinating this trans-organ regulation?" The ability of the liver to deliver AA to peripheral tissues, including the mammary gland, and then react to their demand, is emphasized when hepatic removal is calculated relative to total inflow (summation of portal concentration $\times$ portal plasma flow plus arterial concentration $\times$ hepatic arterial plasma flow), rather than on 
portal absorption of AA. Hepatic removal of AA relative to total inflow was not affected by treatments and averaged $0.04,0.02,0.14$, and 0.14 for histidine, lysine, methionine, and phenylalanine, respectively.

\section{Metabolites and Hormones}

Positive net glucose flux across PDV was observed in both treatments. These results contrast with several studies that report net use (i.e., negative flux) of glucose by total PDV in lactating dairy cows (Lomax and Baird, 1983; Huntington, 1984; Reynolds et al., 1988a). Net absorption of glucose across the gut has been observed; however, in lactating dairy cows fed diets containing corn, as in the present study (Symonds and Baird, 1975; Wieghart et al., 1986; Casse et al., 1994). The type of grain fed probably also influences net portal appearance of glucose (Wieghart et al., 1986). Net PDV fluxes of glucose (whether positive or negative) are usually small, at least compared with TSP release, in animals offered substantial amounts of forage, and only represented $2 \%$ of hepatic production in the current study. Net TSP release of glucose was not affected by the diets, so the increment in lactose milk output with the HiMP diet remains unexplained. Net output of NEFA by the PDV and net uptake by liver were observed in lactating cows (Lomax and Baird, 1983; Reynolds et al., 1988b), a finding confirmed in the present experiment.

Increasing MP supply did not affect insulin fluxes across either the PDV or liver. The net insulin fluxes observed across the PDV are comparable to those reported for early-lactation Holstein cows (Lomax et al., 1979; Reynolds et al., 1989; Casse et al., 1994). Net hepatic fluxes of insulin were lower, however, than those reported in early-lactation cows (Reynolds et al., 1989) but similar to primiparous lactating cows (Casse et al., 1994). The proportion of total inflow of insulin extracted by the liver, averaging $8.7 \%$, was similar to that observed in sheep (Brockman and Bergman, 1975), growing beef steers (Lapierre et al., 1992), and primiparous lactating cows (Casse et al., 1994), but lower than the value of $13 \%$ reported in early-lactation dairy cows (Reynolds et al., 1989). Hepatic removal of insulin relative to net PDV appearance (pancreatic release) averaged $43 \%$, similar to the $50 \%$ observed in sheep (Brockman and Bergman, 1975) but lower than values reported in both lactating (60 to 66\%; Lomax et al., 1979; Reynolds et al., 1989) and dry cows (85\%; Lomax et al., 1979). These observations reinforce the importance of the liver in the net release of insulin to peripheral tissues.

Net removal of glucagon by the liver was lower for the Hi-MP diet than for the Lo-MP diet. Thus, increasing the portal absorption of AA reduced the net hepatic removal of glucagons, although glucagon release by the PDV was unaltered. This is similar to observations in growing steers supplemented with fish meal (Ouellet, 1994). A decrease in the fraction of PDV glucagon release removed by the liver was also reported when casein was infused into the abomasum of growing steers (Guerino et al., 1991b). Although glucagon is considered to regulate positively urea cycle activity and hepatic AA oxidation (Bergman and Pell, 1985), no differences were observed in urea synthesis or AA removal across the liver between diets in the current study.

Arterial concentrations of somatotropin in both treatments were similar to those reported in early-lactation dairy cows (Reynolds et al., 1989), but lower than values observed in growing steers (Lapierre et al., 2000b), as expected, given that somatotropin concentrations usually decrease with age (Abribat et al., 1990). Metabolizable protein supply did not affect arterial IGF-1 concentration. This nonresponsiveness agrees with previous studies on growing beef steers that received either an abomasal infusion of casein (Guerino et al., 1991b) or were supplemented with fish meal (Ouellet, 1994). Positive relationship between IGF-1 concentrations and protein and/or energy intake have been derived from studies where large variations of energy and protein were imposed, as a certain threshold of deprivation needs to be reached to decrease IGF-1 concentrations (Breier et al., 1986). Variations in energy/protein balance could explain, in part, the higher IGF-1 arterial concentration values for cows in late lactation (in positive balance) in the present study compared with cows in early lactation (in negative $\mathrm{N}$ balance; Reynolds et al., 1989).

\section{CONCLUSIONS}

Increased MP supply (estimated to be achieved through increased RUP without altering microbial protein synthesis) resulted in increased portal absorption and posthepatic supply of AA. This led to an increased milk protein output. Between individual AA, the gross efficiency of transfer of portal absorption to milk varied greatly. Different efficiencies between AA were also observed when considering posthepatic supply and utilization for milk protein synthesis. An adequate prediction of the transfer of duodenal protein flow into milk protein requires a better knowledge and understanding of the metabolism of individual AA across the splanchnic tissue and how this may be altered by physiological state and feeding strategies.

\section{ACKNOWLEDGMENTS}

The authors gratefully thank the staff of the Lennoxville dairy center for taking care of the animals, D. 
Bournival, G. Calder, M. Léonard, and A. Roy for their dedicated technical support, as well as S. Méthot for statistical analyses. The authors also wish to acknowledge the financial support of SEERAD (as part of the core budget to the Rowett Research Institute), of the National Sciences and Engineering Research Council of Canada, and of Agriculture and Agri-Food Canada (Lennoxville Research Centre contribution number 751).

\section{REFERENCES}

Abribat, T., H. Lapierre, P. Dubreuil, G. Pelletier, P. Gaudreau, P. Brazeau, and D. Petitclerc. 1990. Insulin-like growth factor concentration in Holstein female cattle: variations with age, stage of lactation and growth hormone-releasing factor administration. Domest. Anim. Endocrinol. 7:93-102.

Association of Official Analytical Chemists. 1984. Official Methods of Analysis. 14th ed. AOAC, Arlington, VA.

Bach, A., G. B. Huntington, S. Calsamiglia, and M. D. Stern. 2000. Nitrogen metabolism of early lactation cows fed diets with two different levels of protein and different amino acid. J. Dairy Sci. 83:2585-2595.

Bequette, B. J., F. R. C. Backwell, J. C. MacRae, G. E. Lobley, L. A. Crompton, J. A. Metcalf, and J. D. Sutton. 1996. Effect of intravenous amino acid infusion on leucine oxidation across the mammary gland of the lactating goat. J. Dairy Sci. 79:2217-2224.

Bergman, E. N., and J. M. Pell. 1985. Integration of amino acid metabolism in the ruminant. Pages 613-628 in Herbivore Nutrition in the Subtropics and Topics. F. M. C. Gilchrist and R. I. Mackie, eds. The Science Press, Johanesburg, South Africa.

Berthiaume, R., P. Dubreuil, M. Stevenson, B. W. McBride, and H. Lapierre. 2001. Intestinal disappearance, mesenteric and portal appearance of amino acids in dairy cows fed ruminally protected methionine. J. Dairy Sci. 84:194-203.

Breier, B. H., J. J. Bass, J. H. Butler, and P. D. Gluckman. 1986. The somatotropic axis in young steers: influence of nutritional status on pulsatile release of growth hormone and circulating concentrations of insulin-like growth factor I. J. Endocrinol. 111:209-215.

Brockman, R. P., and E. N. Bergman. 1975. Quantitative aspects of insulin secretion and its hepatic and renal removal in sheep. Am. J. Physiol. 229:1338-1343.

Bruckental, I., G. B. Huntington, C. Kirk Baer, and R. A. Erdman. 1997. The effect of abomasal infusion of casein and recombinant somatotropin hormone injection on nitrogen balance and amino acid fluxes in portal-drained viscera and net hepatic and total splanchnic blood in Holstein steers. J. Anim. Sci. 75:1119-1129.

Canadian Council on Animal Care. 1993. Guide to the care and use of experimental animals. Vol. 1. E. D. Offert, B. M. Cross, and A. A. McWilliam, eds. CCAC, Ottawa, Ontario, Canada.

Casse, E. A., H. Rulquin, and G. B. Huntington. 1994. Effect of mesenteric vein infusion of propionate on splanchnic metabolism in primiparous Holstein cows. J. Dairy Sci. 77:3296-3303.

Calder, A. G., K. E. Garden, S. E. Anderson, and G. E. Lobley. 1999. Quantitation of blood and plasma amino acids using isotope dilution electron impact gas chromatography/mass spectrometry with $\mathrm{U}^{13} \mathrm{C}$ amino acids as internal standards. Rapid Commun. Mass Spectrom. 13:2080-2083.

De Visser, H., H. Valk, A. Klop, J. Van Der Meulen, J. G. M. Bakker, and G. B. Huntington. 1997. Nutrient fluxes in splanchnic tissue of dairy cows: Influence of grass quality. J. Dairy Sci. 80:16661673.

Goodwin, G. W., W. Gibboney, R. Paxton, R. A. Harris, and J. A. Lemons. 1987. Activities of branched-chain amino acid aminotransferase and branched-chain 2-oxo acid dehyrogease complex in tissues of maternal and fetal sheep. Biochem. J. 242:305-308.

Guerino, F., G. B. Huntington, and R. A. Erdman. 1991a. The net portal and hepatic flux of metabolites and oxygen consumption in growing beef steers given postruminal casein. J. Anim. Sci. 69:387-395.

Guerino, F., G. B. Huntington, R. A. Erdman, T. H. Elsasser, and C. K. Reynolds. 1991b. The effects of abomasal casein infusions in growing beef steers on portal and hepatic flux of pancreatic hormones and arterial concentrations of somatomedin-C. J. Anim. Sci. 69:379-386.

Guinard, J., and H. Rulquin. 1994. Effect of graded levels of duodenal infusions of casein on mammary uptake in lactating cows 2 . Individual amino acids. J. Dairy Sci. 77:3304-3315.

Hanigan, M. D., J. P. Cant, D. C. Weakley, and J. L. Bequett. 1998. An evaluation of postabsorptive protein and amino acid metabolism in the lactating dairy cow. J. Dairy Sci. 81:3385-3401.

Huntington, G. B. 1984. Net absorption of glucose and nitrogenous compounds by lactating Holstein cows. J. Dairy Sci. 67:19191927.

Huntington, G. B. 1987. Net absorption from portal-drained viscera of nitrogenous compounds by beef heifers fed on diets differing in protein solubility or degradability in the rumen. Br. J. Nutr. 57:109-114.

Huntington, G. B., C. K. Reynolds, and B. H. Stroud. 1989. Techniques for measuring blood flow in splanchnic tissues of cattle. J. Dairy Sci. 72:1583-1595.

Huntington, G. B. 1990. Energy metabolism in the digestive tract and liver of cattle: Influence of physiological state and nutrition. Reprod. Nutr. Dev. 30:35-47.

Huntington, G. B. 1997. Starch utilization by ruminants from basics to the bunk. J. Anim. Sci. 75:852-867.

Koeln, L. L., T. G. Schlagheck, and K. E. Webb, Jr. 1993. Amino acid flux across the gastrointestinal tract and liver of calves. J. Dairy Sci. 76:2275-2285.

Katz, M. L., and E. N. Bergman. 1969. Simultaneous measurements of hepatic and portal venous blood flow in the sheep and dog. Am. J. Physiol. 216:946-952.

Lapierre, H., C. K. Reynolds, T. H. Elsasser, P. Gaudreau, P. Brazeau, and H. F. Tyrrell. 1992. Effects of growth hormone-releasing factor and feed intake on energy metabolism in growing beef steers: Net hormone metabolism by portal-drained viscera and liver. J. Anim. Sci. 70:742-750.

Lapierre, H., J. F. Bernier, P. Dubreuil, C. K. Reynolds, C. Farmer, D. R. Ouellet, and G. E. Lobley. 2000a. The effect of feed intake level on splanchnic metabolism in growing beef steers. J. Anim. Sci. 78:1084-1099.

Lapierre, H., C. Farmer, C. K. Reynolds, J. F. Bernier, G. E. Lobley, and P. Dubreuil. 2000b. The effect of intake level on whole body kinetics and hepatic removal of somatotropin in growing beef steers. Domest. Anim. Endocrinol. 18:217-227.

Lapierre, H., and G. E. Lobley. 2001. Nitrogen recycling in the ruminant. J. Dairy Sci. 84(E. Suppl):E223-E236.

Lapierre, H., J. P. Blouin, J. F. Bernier, C. K. Reynolds, P. Dubreuil, and G. E. Lobley. 2002. Effect of supply of metabolizable protein on whole body and splanchnic protein metabolism in lactating dairy cows. J. Dairy Sci. Accepted.

LeFloc'h, N., J. N. Thibault, and B. Séve. 1997. Tissue localization of threonine oxidation in pigs. Br. J. Nutr. 77:593-603.

Lobley, G. E., P. J. M. Weijs, A. Connell, A. G. Calder, D. S. Brown, and E. Milne. 1996. The fate of absorbed and exogenous ammonia as influenced by forage or forage-concentrate diets in growing sheep. Br. J. Nutr. 76:231-248.

Lomax, M. A., G. D. Baird, C. B. Mallison, and H. W. Symonds. 1979. Differences between lactating and non-lactating dairy cows in concentration and secretion rate of insulin. Biochem. J. 180:281-289.

MacRae, J. C., L. A. Bruce, D. S. Brown, D. A. H. Farningham, and M. F. Franklin. 1997. Absorption of amino acids from the intestine and their net flux across the mesenteric and portal drained viscera of lambs. J. Anim. Sci. 75:3307-3314.

McCutcheon, S. N., and D. E. Bauman. 1986. Effect of chronic growth hormone treatment on response to epinephrine and thyrotropinreleasing hormones in lactating cows. J. Dairy Sci. 69:44-51.

McGuire, M. A., D. K. Beede, M. A. DeLorenzo, C. J. Wilcox, G. B. Huntington, C. K. Reynolds, and R. J. Collier. 1989. Effect of 
thermal stress and level of feed intake on portal plasma flow and net fluxes of metabolites in lactating Holstein cows. J. Anim. Sci. 67:1050-1060.

National Research Council. 2001. Nutrient Requirements of Dairy Cattle. 7th rev. ed. Natl. Acad. Sci., Washington, DC.

Ouellet, D. 1994. Métabolismes énergétique et splanchnique des bovins de boucherie alimentés avec des rations à base d'ensilage d'herbe. Ph.D. Diss., Université Laval, Québec, Canada.

Reynolds, C. K., G. B. Huntington, H. F. Tyrrel, and P. J. Reynolds. 1988a. Net portal-drained visceral and hepatic metabolism of glucose, L-lactate, and nitrogenous compounds in lactating Holstein cows. J. Dairy Sci. 71:1803-1812.

Reynolds, C. K., G. B. Huntington, H. F. Tyrrell, and P. J. Reynolds. 1988 b. Net metabolism of volatile fatty acids, D-b-hydroxybutyrate, nonesterified fatty acids, and blood gasses by portal-drained viscera and liver of lactating Holstein cows. J. Dairy Sci. 71:2395-2405.

Reynolds, C. K., G. B. Huntington, T. H. Elsasser, H. F. Tyrrell, and P. J. Reynolds. 1989. Net metabolism of hormones by portaldrained viscera and liver of lactating Holstein cows. J. Dairy Sci. 72:1459-1468.

Reynolds, C. K., D. P. Casper, D. L Harmon, and C. T. Milton. 1992. Effect of $\mathrm{CP}$ and $\mathrm{ME}$ intake on visceral nutrient metabolism in beef steers. J. Anim. Sci. 70 (Suppl. 1):315.

Santos, F. A. P., J. E. P Santos, C. B. Theurer, and J. T. Huber. 1998. Effects of rumen-undegradable protein on dairy cow performance: A 12-year literature review. J. Dairy Sci. 81:3182-3213.
Seal, C. J., and D. S. Parker. 1994. Effect of intraruminal propionic acid infusion on metabolism of mesenteric- and portal-drained viscera in growing steers fed a forage diet: 1 . Volatile fatty acids, glucose and lactate. J. Anim. Sci. 72:1325-1334.

SAS User's Guide: Statistics. Version 5 Edition. 1985.. SAS Inst., Inc., Cary, NC.

Symonds, H. W., and G. D. Baird. 1975. Evidence for the absorption of reducing sugar from the small intestine of the dairy cow. Br. Vet. J. 131:17-21.

Thivierge, M. C., D. Petitclerc, J. F. Bernier, Y. Couture, and H. Lapierre. 2002. Variations of mammary metabolism as the udder gradually fills with milk during a 12-h period following milking: leucine kinetics. J. Dairy Sci. Accepted.

Van Soest, P. J., J. B. Robertson, and B. A. Lewis. 1991. Methods for dietary fiber, neutral detergent fiber, and non-starch polysaccharides in relation to animal nutrition. J. Dairy Sci. 74:34833597.

Wieghart, M., R. Slepetis, J. M. Elliot, and D. F. Smith. 1986. Glucose absorption and hepatic gluconeogenesis in dairy cows fed diets varying in forage content. J. Nutr. 116:839-850.

Wray-Cahen, D., J. A. Metcalf, F. R. C. Backwell, B. J. Bequette, D. S. Brown, J. D. Sutton, and G. E. Lobley 1997. Hepatic response to increased exogenous supply of plasma amino acids by infusion into the mesenteric vein of Holstein-Friesian cows in late gestation. Br. J. Nutr. 78:913-930. 